\title{
Effects of Systemic Propranolol Application on the New Bone Formation in Periimplant Guided Bone Regeneration
}

\author{
Nedim Gunes ${ }^{1}$, Mehmet Gül², Serkan Dundar ${ }^{3}$, Gokhan Artas ${ }^{4}$, Mehmet Ali Kobat ${ }^{5}$, Samet Tekin 6 , \\ Alihan Bozoglan ${ }^{3}$, Abulfaz Isayev ${ }^{7}$ \\ ${ }^{1}$ Department of Oral and Maxillofacial Surgery, Faculty of Dentistry, Dicle University, Diyarbakir, Turkey. \\ ${ }^{2}$ Department of Periodontology, Faculty of Dentistry, Harran University, Sanliurfa, Turkey. \\ ${ }^{3}$ Department of Periodontology, Faculty of Dentistry, Firat University, Elazig, Turkey. \\ ${ }^{4}$ Department of Pathology, Faculty of Medicine, Firat University, Elazig, Turkey. \\ ${ }^{5}$ Department of Cardiology, Faculty of Medicine, Firat University, Elazig, Turkey. \\ ${ }^{6}$ Department of Prosthodontics, Faculty of Dentistry, Firat University, Elazig, Turkey. \\ ${ }^{7}$ Department of Prosthodontics, Goldman School of Dental Medicine, Boston University, Boston, USA.
}

\author{
Corresponding Author: \\ Mehmet Gül \\ Department of Periodontology, Faculty of Dentistry \\ Hamidiye Mah. Harran Üniversitesi \\ Yenişehir Kampüsü, Haliliye, Şanlıurfa \\ Turkey \\ Phone: 05359255812 \\ Fax: +90 4143183190 \\ E-mail: m.gul3838@gmail.com
}

\begin{abstract}
Objectives: The aim of this experimental animal study was to evaluate the effects of systemic propranolol on new bone formation in peri-implant bone defects.

Material and Methods: Implant slots were created $4 \mathrm{~mm}$ long and $2.5 \mathrm{~mm}$ wide. After the titanium implants were placed in the sockets, $2 \mathrm{~mm}$ defects were created in the neck of the implants. Bone grafts were placed in these defects. Then the rats were randomly divided into three equal groups: control $(n=8)$, propranolol dose-1 (PRP-1) $(n=8)$, and propranolol dose-2 $(\mathrm{PRP}-2)(\mathrm{n}=8)$ groups. In the control group, the rats received no further treatment during the eight-week experimental period after the surgery. The rats in the PRP-1 and PRP-2 groups were given $5 \mathrm{mg} / \mathrm{kg}$ and $10 \mathrm{mg} / \mathrm{kg}$ propranolol, respectively, every three days for the eight-week experimental period after the surgery. At the end of the experimental period, the rats were euthanized. Blood serum was collected for biochemical analysis, and the implants and surrounding bone tissues were used for the histological analysis.

Results: There were no significant differences in the histological analysis results and the biochemical parameters (alkaline phosphatase, calcium, creatinine and phosphorus) of the groups $(\mathrm{P}>0.05)$. Also, in the test groups, there was numerically but not statistically more new bone formation detected compared with the controls.

Conclusions: Within the limitations of this study, propranolol did not affect the new bone formation in peri-implant defects.
\end{abstract}

Keywords: bone; peri-implantitis; propranolol; regeneration.

Accepted for publication: 30 September 2021

To cite this article:

Gunes N, Gul M, Dundar S, Artas G, Kobat MA, Tekin S, Bozoglan A, Isayev A.

Effects of Systemic Propranolol Application on the New Bone Formation in Periimplant Guided Bone Regeneration

J Oral Maxillofac Res 2021;12(3):e2

URL: http://www.ejomr.org/JOMR/archives/2021/3/e2/v12n3e2.pdf

doi: $\underline{10.5037 / \text { jomr.2021.12302 }}$ 


\section{INTRODUCTION}

$\beta$-blockers (or beta blockers) are a group of drugs that have a well-known antihypertensive effect by decreasing cardiac output, releasing renin from the kidneys and inhibiting the effect of endogenous catecholamines on $\beta$-adrenoceptors [1]. They act by antagonizing $\beta$-adrenergic receptors and are among the most frequently prescribed cardiovascular drugs, their safe use having long been registered [르, $\underline{3}$. Systemic-acting $\beta$-blockers are broad-spectrum drugs used as antianginal and antihypertensive treatments, for heart failure and arrhythmia and for the symptoms of migraine, anxiety and thyrotoxicosis [1]. Propranolol is reported to inhibit all beta receptors and was the first certified $\beta$-blocker. Although these receptors are secreted primarily from cardiovascular and respiratory cells, they are also secreted from bone cells such as osteoblasts and osteoclasts [4-6]. Studies have reported that antihypertensive drugs are also associated with the bone regeneration process [7-9]. In spontaneously hypertensive rats with ligatureinduced experimental periodontitis, it was observed that the expression of the receptor activator of NK$\mathrm{kB}$ ligand (RANKL) and the RANKL/osteoprotegerin $(\mathrm{OPG})$ ratio were higher in the alveolar bone around the non-ligature teeth, the number of osteoclast cells increased, bone loss increased and bone density decreased. This result is thought to be directly affected by the alveolar bone, regardless of the ligature state [10]. In epidemiological studies, it has been reported that there is a relationship between increased bone loss and high blood pressure. It has also been suggested that $\beta$-blockers are a useful therapeutic in fracture healing and osteoporosis [11-13]. In an implant study, it was reported that the patients were generally healthy, but $38.2 \%$ of the patients had drugcontrolled hypertension and 10\% had controlled type 2 diabetes [14]. In addition, one study suggested that the use of $\beta$-blockers had no effect on bone mineral density [15]. Other research reported that low-dose propranolol use was associated with osteoclastogenesis and inflammatory markers, without affecting haemodynamic parameters. It has been reported that it may suppress periodontal bone resorption [16].

Bone-grafting techniques entail different strategies, such as alveolar distraction and guided bone regeneration (GBR). When the implants are functionally loaded, bone grafting may be undertaken to increase the bone around the implant to ensure osteointegration and maintain implant survival. GBR, which involves reconstruction of the alveolar bone and the treatment of peri-implant bone defects, is one of the commonest methods of bone grafting $[17,18]$. Implanted bone regeneration is required in $40 \%$ of patients who have undergone an implant to complete the healthy osteointegration process [19]. It has been shown that the survival rates of implants placed in areas where GBR is applied are similar to those of implants in areas where it has not been applied [20-22]. The survival rate of implants in the GBR-treated areas varies between 79 and 100\%, and the majority of the implants show a more than $90 \%$ survival rate after at least one year of function [22]. Similarly, the implant survival rate has been reported as $95 \%$ after the horizontal or vertical GBR procedure. Thus, GBR is a successful treatment option that is widely used in alveolar bone defects and implant applications $[\underline{17}, \underline{23}, 24]$.

In this study, we postulate that a $\beta$-blocker (propranolol) can be used together with a bone graft to reduce defects and bone loss around dental implants. As far as we know, there is no specific information about the low-, medium- and high-dose effects of propranolol on tissues surrounding peri-implants or on the mechanism of action. Accordingly, the effects of different doses of propranolol and graft material on bone defects around experimental implants were evaluated.

The aim of this experimental animal study was to evaluate the effect of propranolol on graft application in periimplant bone defects in rats treated with systemic propranolol.

\section{MATERIAL AND METHODS Study design}

This study was conducted at Frrat University Experimental Research Center between December 16, 2019 and February 17, 2020, after obtaining approval from Firat University Animal Experiments Local Ethics Committee (Protocol No. 2019/143). The subjects were provided by Firat University Experimental Research Center.

Twenty-four Sprague-Dawley rats were used in the experiment. The rats were randomly divided into three groups ( $n=8$ in each group). Rats were kept on a light/dark cycle for an equal period of time. In addition, humidity (55\%) and temperature (22 [SD 2] ${ }^{\circ} \mathrm{C}$ ) were continuously controlled. The subjects were kept in pairs in cages. Normal diet, water and ad libitum nutrition were provided. The implants which we used in this study have resorbable blast material (RBM) surfaced and threat depth $0.3 \mathrm{~mm}$, threat pitch $0.4 \mathrm{~mm}, 2.5 \mathrm{~mm}$ diameter and $4 \mathrm{~mm}$ long with 8 threads (AGS Medical Corporation; Istanbul, Turkey). 
In order to standardize the defects, a 3-walled standard defect with $2.5 \mathrm{~mm}$ width and $2 \mathrm{~mm}$ length was opened on one side of the implants with the drill in which the implant slots were opened. After the grafts were placed, the defect area was closed with resorbable collagen membrane (Jason membrane ${ }^{\circledR}$ Botiss Biomaterials GmbH; Zossen, Germany).

\section{Surgical procedures}

General anaesthesia was created by intraperitoneal injection of ketamine hydrochloride $(50 \mathrm{mg} / \mathrm{kg}$, Ketasol $^{\circledR}$ - Richter Pharma AG; Wels, Austria) and xylazine $\left(5 \mathrm{mg} / \mathrm{kg}\right.$, Rompun ${ }^{\circledR}$ - Bayer HealthCare AG; Leverkusen, Germany) to rats. All surgical procedures were performed under sterile conditions. After anaesthesia, the operation area was cleaned with povidone-iodine and shaved. RBM titanium implants were placed in the metaphyseal part of the tibial bone. After placing the titanium implants, the flap was returned to its original position and sutured with 4-0 polyglactin sutures. Antibiotics $(50 \mathrm{mg} / \mathrm{kg}$ penicillin) and analgesic $(0.1 \mathrm{mg} / \mathrm{kg}$ tramadol hydrochloride $)$ were administered intramuscularly daily to rats for three days after surgical procedures.

Group 1 (control group): implant sockets were created in the corticocancellous bone in the metaphyseal parts of the right tibial bones of the rats. These sockets were fitted with $2.5 \mathrm{~mm}$-diameter, $4 \mathrm{~mm}$-long titanium screws, and the hydroxyapatite bone graft of bovine origin $\left(\right.$ Cerabone $^{\circledR}$ - Botiss Biomaterials $\mathrm{GmbH}$; Zossen, Germany) was placed in the bone defect that would occur in the neck region, corresponding to 2 $\mathrm{mm}$ of the implant length. No additional treatment was performed during the eight-week experimental setup.

Group 2 (propranolol-graft dose-1 [PRP-1] group): implant sockets were created, the sockets fitted with titanium screws and the bone graft placed in the bone defect, as in Group 1. In this group, $5 \mathrm{mg} / \mathrm{kg}$ propranolol was administered orally three days a week during the eight-week experiment [25].

Group 3 (propranolol-graft dose-2 [PRP-2] group): implant sockets were created, the sockets fitted with titanium screws and the bone graft placed in the bone defect, as in Group 1. The subjects in this group were administered $10 \mathrm{mg} / \mathrm{kg}$ propranolol oral gavage three days a week during the eight-week experiment [25] At the end of the eight-week experimental setup, all rats were sacrificed.

\section{Histological analysis}

The implants and bone tissue around them were removed and decalcified before being subjected to histological analysis at the Frrat University Faculty of Medicine Pathology Laboratory. The histological analysis was performed on the original graft bone tissue. The samples were stored in $10 \%$ formaldehyde solution for 72 hours. Minerals were eliminated in $10 \%$ formic acid solution. The implants were removed from the samples without damaging the bone tissue. Dehydration of the bone tissue samples was performed for analysis. The samples were embedded in a paraffin wax block. Microscopic haematoxylin and eosin analysis was performed.

Light microscopy was used to examine $6 \mu \mathrm{m}$ thick sections of bone graft samples. An image analysis program was used to evaluate the new bone formation. The newly formed bone area was calculated as a percentage of the total area of new bone area formed in peri-implant bone tissues. All histological samples were examined by means of images taken with a digital camera connected to a light microscope and transferred to a computer with original magnification [26]. Histomorphometric analyses were performed with a device fitted with an Olympus DP71 (Olympus Corp.; Tokyo, Japan) software imaging system. The new boneformation rate for each implant was calculated by the ratio of the newly formed bone surface to the grafted surface. The data were recorded as percentages $(\%)$.

\section{Biochemical analysis}

While the rats were in deep anaesthesia, blood samples were collected through cardiac puncture without anticoagulant to measure the serum alkaline phosphatase (ALP), calcium (Ca), creatinin (Cr) and phosphorus (P). Biochemical data were measured for each rat at the central biochemistry laboratory of the Faculty of Medicine Firat University.

\section{Statistical analysis}

Statistical analyses were performed using IBM SPSS version 23.0 (IBM Inc.; Chicago, Illinois, USA). The data in each group were given as mean and standard deviation (M [SD]). One-way ANOVA was used to determine the differences between groups. Tukey's honest significant difference test was used to determine the group that caused the differences $(\mathrm{P}<0.05)$. The student's t-test was used to determine the differences between the test groups (PRP-1 and PRP-2) and the control group $(\mathrm{P}<0.05)$. 


\section{RESULTS}

Although the histological analyses showed no statistical differences between the control group (47.63\% [5.01]) and PRP-1 (49.25\% [7.38]) and PRP2 (51\% [8.8]), higher new bone-formation values were obtained in the PRP-1 and PRP-2 groups (Table 1). In addition, when the control group and both the two propranolol groups were compared, although higher values were obtained in the latter, again no statistically significant difference was obtained between them (control: 47.63\% [5.01], PRP-1 + PRP2: 50.13\% [7.9]) (Table 1 and Figures 1, 2).

Biochemical analysis evaluated the ALP, Ca, P and $\mathrm{Cr}$ levels after the administration of different doses of propranolol. The ALP (U/L) level was found to be lower in both the propranolol groups compared to the control group (control: 137.87 [37.12], PRP1: 61.38 [11.5], PRP-2: 89.88 [72.07]). However, no statistically significant difference was found between the control group and the propranolol groups $(\mathrm{P}=$ 0.259). In addition, when compared with the control group and the two propranolol groups, although lower ALP values were obtained in the latter, no statistically significant difference was found between them $(\mathrm{P}>$ 0.05; control: 137.88 [37.12], PRP-1 + PRP-2: 75.63 [51.98]). In the analysis of $\mathrm{Ca}(\mathrm{mg} / \mathrm{dl})$ levels, only the PRP-1 group was found to have a lower level (control: 10.17 [0.57], PRP-1: 9.88 [1.3], PRP-2: 10.14 [1.75]), the difference being small and not statistically significantly different $(\mathrm{P}=0.892)$. In addition, when compared with the control group and both propranolol groups, although lower $\mathrm{Ca}$ values were obtained in the propranolol groups, no statistically significant difference was found between them $(\mathrm{P}>0.05$; control: 10.17 [0.57], PRP-1 + PRP-2: 10.01 [1.49]). P (mg/dl) levels in the three groups were similar (control: 6.18 [0.47], PRP-1: 5.86 [0.56], PRP-2: 6.19 [1.48]), with no significant difference between them $(\mathrm{P}=0.745)$. In addition, when compared with the control group and the two propranolol groups, although lower $\mathrm{P}$ values were obtained in the latter, no statistically significant difference was found between them $(\mathrm{P}>0.05$; control: 6.18 [0.47], PRP-1 + PRP-2: 6.03 [1.09]). Cr (mg/ dl) levels were $0.55(0.08)$ in the control group, $0.52(0.09)$ in the PRP-1 group and $0.57(0.12)$ in the PRP-2 group, and no statistical difference was found between them $(P>0.05)$. In addition, when compared with the control group and the propranolol groups, although lower $\mathrm{Cr}$ values were obtained in the propranolol groups, no statistically significant difference was found between them $(\mathrm{P}>0.05$; Table 2).

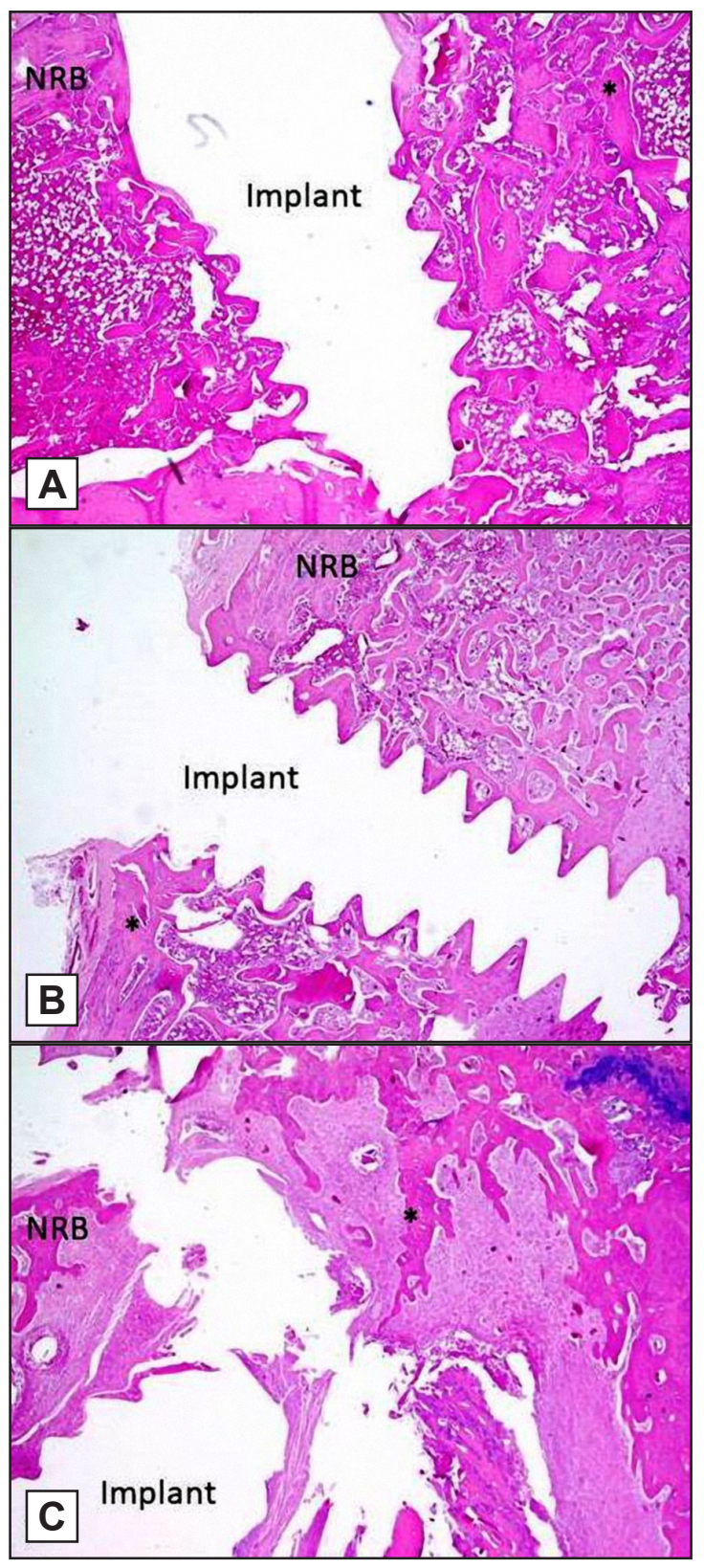

Figure 1. Decalcified histologic images (hematoxylin and eosin stain, original magnification $\mathrm{x} 40,200 \mu \mathrm{m})$ : $\mathrm{A}=$ control; $\mathrm{B}=$ propranolol dose-1; $\mathrm{C}=$ propranolol dose-2. The new bone-formation ratio for each implant was calculated by the ratio of the newly formed bone tissue to the grafted area. The data were recorded as percentages $(\%) . \mathrm{NRB}=$ newly regenerated bone; $*=$ bone tissue.

Table 1. New bone formation (NBF) of the groups

\begin{tabular}{l|c|c|c}
\hline \multirow{2}{*}{ Groups } & \multirow{2}{*}{ N } & NBF (\%) & \multirow{2}{*}{ P } \\
\cline { 3 - 3 } & & Mean (SD) & \\
\hline Control & 8 & $47.63(5.01)$ & \multirow{2}{*}{$>0.05^{\mathrm{a}}$} \\
\hline PRP-1 & 8 & $49.25(7.38)$ & \\
\hline PRP-2 & 8 & $51(8.8)$ & \\
\hline Control & 8 & $47.63(5.01)$ & \multirow{2}{*}{$>0.05^{\mathrm{b}}$} \\
\hline PRP-1 + PRP-2 & 16 & $50.13(7.9)$ & \\
\hline
\end{tabular}

${ }^{\text {aNot }}$ statistically significant at level $\mathrm{P}<0.05$ (One-way ANOVA). ${ }^{b}$ Not statistically significant at level $\mathrm{P}<0.05$ (Student's t-test). $\mathrm{N}=$ number of subjects; $\mathrm{SD}=$ standard deviation; PRP-1 = propranolol dose-1; PRP-2 = propranolol dose- 2 . 


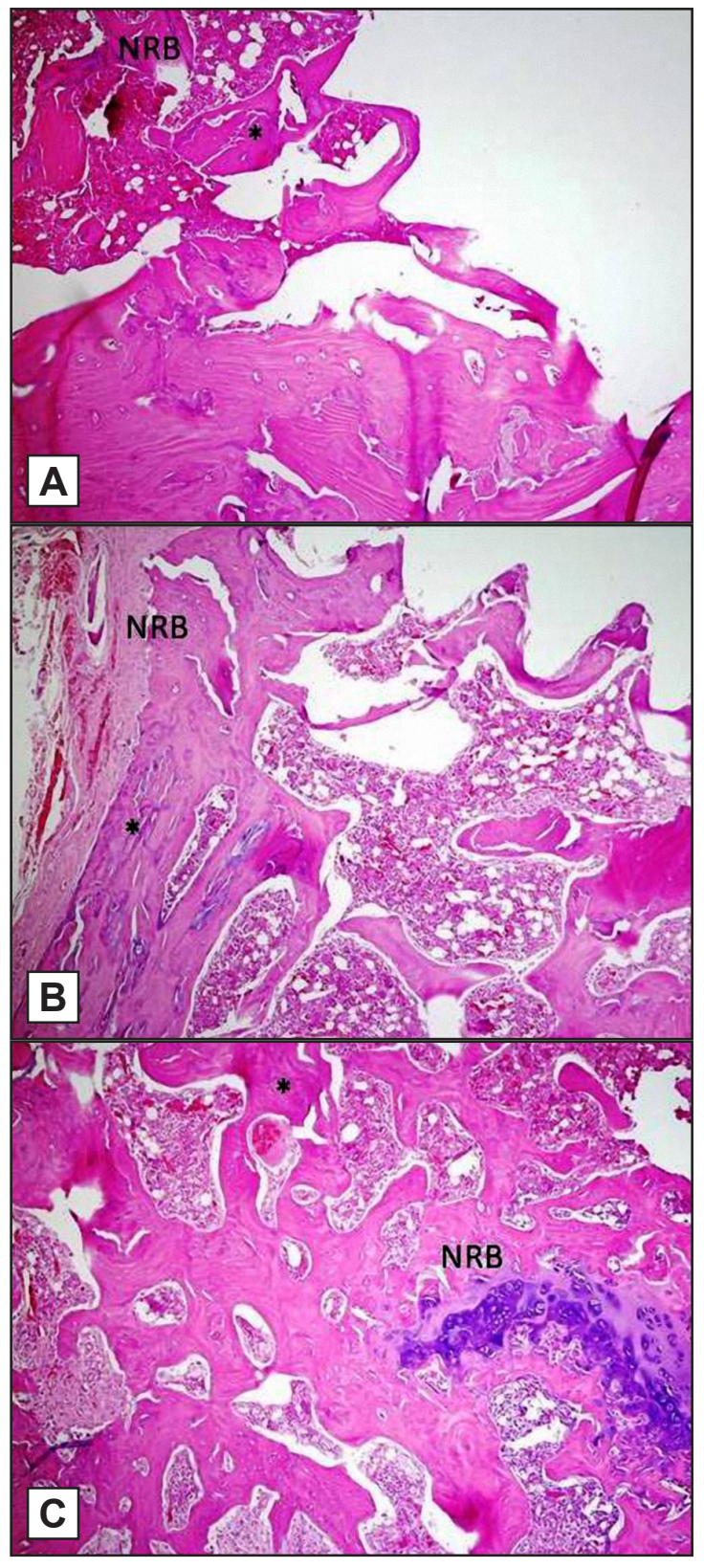

Figure 2. Decalcified histologic images (hematoxylin and eosin stain, original magnification $\times 100,500 \mu \mathrm{m}): \mathrm{A}=$ control; $\mathrm{B}=$ propranolol dose-1; C = propranolol dose-2. The new bone-formation ratio for each implant was calculated by the ratio of the newly formed bone tissue to the grafted area. NRB = newly regenerated bone; * = bone tissue.

\section{DISCUSSION}

Okada et al. [27] suggested that applying $\beta$-blockers (propranolol) at low doses can prevent periodontal bone loss by reducing bone resorption. In a study by Rodrigues et al. [16], it was suggested that the effects of $\beta$-blockers on bone at low doses are partly due to the inhibition of inflammatory markers and osteoclastogenesis, without affecting heart function. Some studies have shown that periodontal tissue is controlled by the autonomic nervous system,
Table 2. Biochemical parameters of the groups

\begin{tabular}{|c|c|c|c|c|}
\hline Parameters & Groups & $\mathbf{N}$ & Mean (SD) & $\begin{array}{c}\mathbf{P} \\
\text { value }\end{array}$ \\
\hline \multirow{3}{*}{$\operatorname{ALP}(\mathbf{U} / \mathbf{L})$} & Control & 8 & $137.88(37.12)$ & \multirow{12}{*}{$>0.05^{\mathrm{a}}$} \\
\hline & PRP-1 & 8 & $61.38(11.5)$ & \\
\hline & PRP-2 & 8 & $89.88(72.07)$ & \\
\hline \multirow{3}{*}{$\mathrm{Ca}(\mathrm{mg} / \mathrm{dl})$} & Control & 8 & $10.17(0.57)$ & \\
\hline & PRP-1 & 8 & $9.88(1.3)$ & \\
\hline & PRP-2 & 8 & $10.14(1.75)$ & \\
\hline \multirow{3}{*}{$P(\mathrm{mg} / \mathrm{dl})$} & Control & 8 & $6.18(0.47)$ & \\
\hline & PRP-1 & 8 & $5.86(0.56)$ & \\
\hline & PRP-2 & 8 & $6.19(1.48)$ & \\
\hline \multirow{3}{*}{$\mathrm{Cr}(\mathrm{mg} / \mathrm{dl})$} & Control & 8 & $0.55(0.08)$ & \\
\hline & PRP-1 & 8 & $0.52(0.09)$ & \\
\hline & PRP-2 & 8 & $0.57(0.12)$ & \\
\hline \multirow[b]{2}{*}{$\operatorname{ALP}(\mathbf{U} / \mathbf{L})$} & Controls & 8 & $137.88(37.12)$ & \multirow{8}{*}{$>0.05^{b}$} \\
\hline & $\begin{array}{c}\text { Test } \\
\text { (PRP-1 and PRP-2) }\end{array}$ & 16 & $75.63(51.98)$ & \\
\hline \multirow[b]{2}{*}{$\mathrm{Ca}(\mathrm{mg} / \mathrm{dl})$} & Controls & 8 & $10.17(0.57)$ & \\
\hline & $\begin{array}{c}\text { Test } \\
\text { (PRP-1 and PRP-2) }\end{array}$ & 16 & $10.01(1.49)$ & \\
\hline \multirow[b]{2}{*}{$P(\mathbf{m g} / \mathrm{dl})$} & Controls & 8 & $6.18(0.47)$ & \\
\hline & $\begin{array}{c}\text { Test } \\
\text { (PRP-1 and PRP-2) } \\
\end{array}$ & 16 & $6.03(1.09)$ & \\
\hline \multirow[b]{2}{*}{$\mathrm{Cr}(\mathrm{mg} / \mathrm{dl})$} & Controls & 8 & $0.56(0.08)$ & \\
\hline & $\begin{array}{c}\text { Test } \\
\text { (PRP-1 and PRP-2) }\end{array}$ & 16 & $0.55(0.1)$ & \\
\hline
\end{tabular}

${ }^{a}$ Not statistically significant at level $\mathrm{P}<0.05$ (One-way ANOVA).

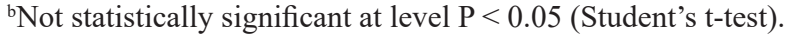
$\mathrm{N}=$ number of subjects; $\mathrm{SD}=$ standard deviation; $\mathrm{PRP}=$ propranolol; $\mathrm{ALP}=$ alkaline phosphatase $\mathrm{Ca}=$ calcium; $\mathrm{P}=$ phosphorus; $\mathrm{Cr}=$ creatinine; $\mathrm{PRP}-1=$ propranolol dose- 1 PRP-2 = propranolol dose-2.

especially the sympathetic nervous system, and dysfunction of this system can lead to periodontal disruption $[\underline{28}, \underline{29}]$. Togari et al. [30] indicated that the downregulation of bone formation depends on the activation of $\beta 2$-adrenergic receptors, which are known to be expressed only by osteoblasts. However, Rodrigues et al. [16] stated that there is less bone resorption between bones and a protective effect on the bone in ligated animals treated with low doses of propranolol $(0.1$ and $5 \mathrm{mg} / \mathrm{kg})$. Pierroz et al. [31] showed that propranolol could not completely recover bone loss in adult mice undergoing ovariectomy, and pharmacological studies on adrenergic receptors gave controversial results. Minkowitz et al. [32] formed bone fractures in rats, then applied propranolol therapy $(0.1 \mathrm{mg} / \mathrm{kg})$ for 12 weeks, and found metaphysis and increased bone formation in both the periosteum and the endosteum. They investigated whether propranolol administered systemically at low doses had an effect on bone metabolism and caused an increase in orthotopic endochondral bone 
formation. As a result of biomechanical tests in the non-surgical group, they reported that systemically administered propranolol increased femoral torsional strength. In rats undergoing surgical procedures, the right femoral bones were fixed with a polyethylene plate and the defect was filled with demineralized bone matrix after defects were formed in the middle part of the diaphysis. Analyses performed on imperfect rats showed that trabecular femoral metaphyseal mineral apposition rates increased when treated with propranolol. Increased callus and bone fusion was reported after 12 weeks in rats treated with propranolol. The researchers reported that systemic propranolol treatment can significantly affect bone properties [32]. Bonnet et al. [33] reported that low-dose $\beta$-blockers can be useful as a therapeutic agent in the treatment of osteoporosis by showing high selectivity in bone tissues, and this supports our results regarding periodontal bone diseases.

In the present study, different doses of propranolol were applied after bone grafting around the implant to increase bone healing and implant osteointegration. Histologically, higher levels of new bone were detected in the groups that received propranolol. However, this difference was not statistically significant. In their experimental study of rat tibiae, Al-Subaie et al. [25] reported that propranolol enhanced bone healing and implant osseointegration. Propranolol-treated rats were found to present smaller cortical defects with more bone volume/tissue volume compared to controls. Propranolol also enhanced osseointegration, as propranolol-treated rats exhibited higher bone-implant contact (and peri-implant bone volume/tissue volume) than control animals.

Similarly to previous studies, we found that propanol administration increased bone-implant contact at different doses. However, no statistically significant difference was found.

Propranolol has been reported to reduce serum ALP and alanine aminotransferase (ALT) levels alone and in combination with ginger [34]. In a study by Abrar et al. [35], ALT, ALP and gamma-glutamyltransferase $(\gamma \mathrm{GT})$ levels were measured and found to be significantly higher in the rifampicin (RIF) $(100 \mathrm{mg} /$ $\mathrm{kg}$ ) group compared to the control group that received distilled water, and the group that received RIF (100 $\mathrm{mg} / \mathrm{kg}$ ) and propranolol (30 $\mathrm{mg} / \mathrm{kg})$ daily. Our study confirmed that ALP levels were lower in the groups treated with propanol.

\section{Limitations}

Molecular mechanisms related to changes in bone metabolism after systemic propranolol administration has not been fully explained. In vivo studies are important to determine the pathways underlying the anti-bone-absorbing effects of propranolol, but the results can only be used to predict the corresponding pathways in humans. In addition, implants are applied to various bones in the body (such as mandiblemaxilla). Due to the application of the experiment to the tibia, the results may be different in implants applied to different regions [주] .

\section{CONCLUSIONS}

In the present study, alkaline phosphatase values were found lower in the groups treated with propranolol, although the difference was not statistically significant. Thus, in our new bone formation study in implants, different doses of propranolol were applied in grafting, but no statistically significant differences were obtained, despite evidence of positive results from the applied propranolol compared to the control group. More studies are needed to better understand the effects of propranolol.

\section{ACKNOWLEDGMENTS AND DISCLOSURE STATEMENTS}

The authors wish to thank Implance Dental Implant System (AGS Medical Corporation; Istanbul, Turkey) for manufacturing and providing the titanium implants. The authors declare that they have no conflicts of interest and no financial interests, either directly or indirectly, in the products or information mentioned in the paper. No funding was received for the study.

\section{REFERNCES}

1. Graham S, Hammond-Jones D, Gamie Z, Polyzois I, Tsiridis E, Tsiridis E. The effect of beta-blockers on bone metabolism as potential drugs under investigation for osteoporosis and fracture healing. Expert Opin Investig Drugs. 2008 Sep;17(9):1281-99. [Medline: 18694363] [doi: 10.1517/13543784.17.9.1281]

2. Stapleton MP. Sir James Black and propranolol. The role of the basic sciences in the history of cardiovascular pharmacology. Tex Heart Inst J. 1997;24(4):336-42. [Medline: 9456487] [PMC free article: 325477] 
3. Freemantle N, Cleland J, Young P, Mason J, Harrison J. beta Blockade after myocardial infarction: systematic review and meta regression analysis. BMJ. 1999 Jun 26;318(7200):1730-7. [Medline: 10381708] [PMC free article: 31101] [doi: $10.1136 /$ bmj.318.7200.1730]

4. Arcangelo VP, Peterson AM. Pharmacotherapeutics for advanced practice: a practical approach. Philadelphia: Lippincott Williams \& Wilkins; 2006; (Vol. 536). p. 959.

5. Togari A. Adrenergic regulation of bone metabolism: possible involvement of sympathetic innervation of osteoblastic and osteoclastic cells. Microsc Res Tech. 2002 Jul 15;58(2):77-84. [Medline: 12203706] [doi: 10.1002/jemt.10121]

6. Elefteriou F, Ahn JD, Takeda S, Starbuck M, Yang X, Liu X, Kondo H, Richards WG, Bannon TW, Noda M, Clement K, Vaisse C, Karsenty G. Leptin regulation of bone resorption by the sympathetic nervous system and CART. Nature. 2005 Mar 24;434(7032):514-20. [Medline: 15724149] [doi: 10.1038/nature03398]

7. García-Denche JT, Wu X, Martinez PP, Eimar H, Ikbal DJ, Hernández G, López-Cabarcos E, Fernandez-Tresguerres I, Tamimi F. Membranes over the lateral window in sinus augmentation procedures: a two-arm and split-mouth randomized clinical trials. J Clin Periodontol. 2013 Nov;40(11):1043-51. [Medline: 24164570] [doi: 10.1111/jcpe.12153]

8. Wu X, Al-Abedalla K, Eimar H, Arekunnath Madathil S, Abi-Nader S, Daniel NG, Nicolau B, Tamimi F. Antihypertensive Medications and the Survival Rate of Osseointegrated Dental Implants: A Cohort Study. Clin Implant Dent Relat Res. 2016 Dec;18(6):1171-1182. [Medline: 26935774] [doi: 10.1111/cid.12414]

9. Morrison MD, Tamimi F. Oral tori are associated with local mechanical and systemic factors: a case-control study. J Oral Maxillofac Surg. 2013 Jan;71(1):14-22. [Medline: 23010373] [doi: 10.1016/i.joms.2012.08.005]

10. Bastos MF, Brilhante FV, Gonçalves TE, Pires AG, Napimoga MH, Marques MR, Duarte PM. Hypertension may affect tooth-supporting alveolar bone quality: a study in rats. J Periodontol. 2010 Jul;81(7):1075-83. [Medline: 20350157] [doi: 10.1902/jop.2010.090705]

11. Cappuccio FP, Meilahn E, Zmuda JM, Cauley JA. High blood pressure and bone-mineral loss in elderly white women: a prospective study. Study of Osteoporotic Fractures Research Group. Lancet. 1999 Sep 18;354(9183):971-5. [Medline: 10501357] [doi: 10.1016/S0140-6736(99)01437-3]

12. Pasco JA, Henry MJ, Sanders KM, Kotowicz MA, Seeman E, Nicholson GC; Geelong Osteoporosis Study. Beta-adrenergic blockers reduce the risk of fracture partly by increasing bone mineral density: Geelong Osteoporosis Study. J Bone Miner Res. 2004 Jan;19(1):19-24. [Medline: 14753732] [doi: 10.1359/jbmr.0301214]

13. Schlienger RG, Kraenzlin ME, Jick SS, Meier CR. Use of beta-blockers and risk of fractures. JAMA. 2004 Sep 15;292(11):1326-32. [Medline: 15367554] [doi: 10.1001/jama.292.11.1326]

14. Svezia L, Casotto F. Short Dental Implants $(6 \mathrm{~mm})$ Versus Standard Dental Implants (10 mm) Supporting Single Crowns in the Posterior Maxilla and/or Mandible: 2-Year Results from a Prospective Cohort Comparative Trial. J Oral Maxillofac Res. 2018 Sep 30;9(3):e4. [Medline: 30429964] [PMC free article: 6225597] [doi: 10.5037/jomr.2018.9304]

15. Reid IR, Lucas J, Wattie D, Horne A, Bolland M, Gamble GD, Davidson JS, Grey AB. Effects of a beta-blocker on bone turnover in normal postmenopausal women: a randomized controlled trial. J Clin Endocrinol Metab. 2005 Sep;90(9): 5212-6. [Medline: 15998769] [doi: 10.1210/jc.2005-0573]

16. Rodrigues WF, Madeira MF, da Silva TA, Clemente-Napimoga JT, Miguel CB, Dias-da-Silva VJ, Barbosa-Neto O, Lopes AH, Napimoga MH. Low dose of propranolol down-modulates bone resorption by inhibiting inflammation and osteoclast differentiation. Br J Pharmacol. 2012 Apr;165(7):2140-51. [Medline: 21950592] [PMC free article: 3413852 ] [doi: 10.1111/j.1476-5381.2011.01686.x]

17. Elgali I, Omar O, Dahlin C, Thomsen P. Guided bone regeneration: materials and biological mechanisms revisited. Eur J Oral Sci. 2017 Oct;125(5):315-337. [Medline: 28833567] [PMC free article: 5601292] [doi: 10.1111/eos.12364]

18. Liu J, Kerns DG. Mechanisms of guided bone regeneration: a review. Open Dent J. 2014 May 16;8:56-65. [Medline: 24894890] [PMC free article: 4040931] [doi: 10.2174/1874210601408010056]

19. Bornstein MM, Halbritter S, Harnisch H, Weber HP, Buser D. A retrospective analysis of patients referred for implant placement to a specialty clinic: indications, surgical procedures, and early failures. Int J Oral Maxillofac Implants. 2008 Nov-Dec;23(6):1109-16. [Medline: 19216281]

20. Donos N, Mardas N, Chadha V. Clinical outcomes of implants following lateral bone augmentation: systematic assessment of available options (barrier membranes, bone grafts, split osteotomy). J Clin Periodontol. 2008 Sep;35(8 Suppl):173-202. [Medline: 18724850$]$ [doi: $\underline{10.1111 / j .1600-051 X .2008 .01269 . x}$ ]

21. Clementini M, Morlupi A, Canullo L, Agrestini C, Barlattani A. Success rate of dental implants inserted in horizontal and vertical guided bone regenerated areas: a systematic review. Int J Oral Maxillofac Surg. 2012 Jul;41(7):847-52. [Medline: 22542079] [doi: 10.1016/j.ijom.2012.03.016]

22. Jensen SS, Terheyden H. Bone augmentation procedures in localized defects in the alveolar ridge: clinical results with different bone grafts and bone-substitute materials. Int J Oral Maxillofac Implants. 2009;24 Suppl:218-36. [Medline: 19885447]

23. Hämmerle $\mathrm{CH}$, Jung RE, Feloutzis A. A systematic review of the survival of implants in bone sites augmented with barrier membranes (guided bone regeneration) in partially edentulous patients. J Clin Periodontol. 2002;29 Suppl 3:226-31; discussion 232-3. [Medline: 12787222] [doi: 10.1034/j.1600-051X.29.s3.14.x] 
24. Aghaloo TL, Moy PK. Which hard tissue augmentation techniques are the most successful in furnishing bony support for implant placement? Int J Oral Maxillofac Implants. 2007;22 Suppl:49-70. Erratum in: Int J Oral Maxillofac Implants. 2008 Jan-Feb;23(1):56. [Medline: 18437791]

25. Al-Subaie AE, Laurenti M, Abdallah MN, Tamimi I, Yaghoubi F, Eimar H, Makhoul N, Tamimi F. Propranolol enhances bone healing and implant osseointegration in rats tibiae. J Clin Periodontol. 2016 Dec;43(12):1160-1170. [Medline: 27706837] [doi: 10.1111/jcpe.12632]

26. Raposo-Ferreira TM, Salvador RC, Terra EM, Ferreira JH, Vechetti-Junior IJ, Tinucci-Costa M, Rogatto SR, LauferAmorim R. Evaluation of vascular endothelial growth factor gene and protein expression in canine metastatic mammary carcinomas. Microsc Res Tech. 2016 Nov;79(11):1097-1104. [Medline: 27543935] [doi: 10.1002/jemt.22763]

27. Okada Y, Hamada N, Kim Y, Takahashi Y, Sasaguri K, Ozono S, Sato S. Blockade of sympathetic b-receptors inhibits Porphyromonas gingivalis-induced alveolar bone loss in an experimental rat periodontitis model. Arch Oral Biol. 2010 Jul;55(7):502-8. [Medline: 20593554] [doi: 10.1016/j.archoralbio.2010.04.002]

28. Breivik T, Gundersen Y, Opstad PK, Fonnum F. Chemical sympathectomy inhibits periodontal disease in Fischer 344 rats. J Periodontal Res. 2005 Aug;40(4):325-30. [Medline: 15966910] [doi: 10.1111/j.1600-0765.2005.00803.x]

29. Kim Y, Hamada N, Takahashi Y, Sasaguri K, Tsukinoki K, Onozuka M, Sato S. Cervical sympathectomy causes alveolar bone loss in an experimental rat model. J Periodontal Res. 2009 Dec;44(6):695-703. [Medline: 19453856] [doi: 10.1111/j.1600-0765.2008.01177.x]

30. Togari A, Arai M, Mizutani S, Mizutani S, Koshihara Y, Nagatsu T. Expression of mRNAs for neuropeptide receptors and beta-adrenergic receptors in human osteoblasts and human osteogenic sarcoma cells. Neurosci Lett. 1997 Sep 19; 233(2-3):125-8. [Medline: 9350848] [doi: 10.1016/S0304-3940(97)00649-6]

31. Pierroz DD, Bouxsein ML, Rizzoli R, Ferrari SL. Combined treatment with a beta-blocker and intermittent PTH improves bone mass and microarchitecture in ovariectomized mice. Bone. 2006 Aug;39(2):260-7. [Medline: 16531131] [doi: 10.1016/j.bone.2006.01.145]

32. Minkowitz B, Boskey AL, Lane JM, Pearlman HS, Vigorita VJ. Effects of propranolol on bone metabolism in the rat. J Orthop Res. 1991 Nov;9(6):869-75. [Medline: 1919850] [doi: 10.1002/jor.1100090613]

33. Bonnet N, Benhamou CL, Malaval L, Goncalves C, Vico L, Eder V, Pichon C, Courteix D. Low dose beta-blocker prevents ovariectomy-induced bone loss in rats without affecting heart functions. J Cell Physiol. 2008 Dec;217(3): 819-27. [Medline: 18727092] [doi: 10.1002/jep.21564]

34. Abdelsameea AA, El-menshawy SS, Pasha HF, Emara MW. Effects and Interactions of Ginger and Propranolol in PreHepatic Portal Hypertensive Rats. Clin Exp Pharmacol. 2015; 5(4) 179: 2161-1459. [doi: 10.4172/2161-1459.1000179]

35. Abrar H, Ahmed MR, Ali AB, Yasin H, Ibrahim S. Effect of propranolol on hepatic blood flow for reduction of the hepatotoxicity of rifampicin in rabbits. Med Forum Monthly. 2017 Jul; 28(7):105-109.

36. Dundar S, Bozoglan A, Bulmus O, Tekin S, Yildirim TT, Kirtay M, Toy VE, Gul M, Bozoglan MY. Effects of restraint stress and high-fat diet on osseointegration of titanium implants: an experimental study. Braz Oral Res. 2020 Feb 7;34:e008. [Medline: 32049109] [doi: 10.1590/1807-3107bor-2020.vol34.0008]

\section{To cite this article:}

Gunes N, Gul M, Dundar S, Artas G, Kobat MA, Tekin S, Bozoglan A, Isayev A.

Effects of Systemic Propranolol Application on the New Bone Formation in Periimplant Guided Bone Regeneration

J Oral Maxillofac Res 2021;12(3):e2

URL: http://www.ejomr.org/JOMR/archives/2021/3/e2/v12n3e2.pdf

doi: $10.5037 /$ jomr.2021.12302

Copyright (C) Gunes N, Gul M, Dundar S, Artas G, Kobat MA, Tekin S, Bozoglan A, Isayev A. Published in the JOURNAL OF ORAL \& MAXILLOFACIAL RESEARCH (http://www.ejomr.org), 30 September 2021.

This is an open-access article, first published in the JOURNAL OF ORAL \& MAXILLOFACIAL RESEARCH, distributed under the terms of the Creative Commons Attribution-Noncommercial-No Derivative Works 3.0 Unported License, which permits unrestricted non-commercial use, distribution, and reproduction in any medium, provided the original work and is properly cited. The copyright, license information and link to the original publication on (http://www.ejomr.org) must be included. 